\title{
Personal Laws: Undetermined Norms and Undetermined Concept?
}

\author{
Jean-Louis Halpérin ${ }^{1}$ \\ Published online: 7 August 2019 \\ (c) Springer Nature B.V. 2019
}

\begin{abstract}
Many Asian and African constitutional and statutory texts use the phrase personal laws in order to determine the rules applicable to family matters such a marriage, divorce, maintenance and in some countries inheritance. However, this term is extremely vague and often without a clear definition in the legal texts. This paper tries to show the high degree of un-determination of the statutory references to personal laws. This chaotic situation can be explained by historical and political factors. Nevertheless, the paper proposes to stipulate a conventional definition of personal laws in order to facilitate the comparison between the Asian and African countries with a plurality of personal laws. Based on common features of these legal systems knowing a plurality of personal laws, such a definition can be useful for practical as well as for theoretical purposes.
\end{abstract}

Keywords Africa $\cdot$ Asia $\cdot$ Legal concept $\cdot$ Legal pluralism $\cdot$ Personal law

\section{Introduction}

Personal law is one of those technical terms used by jurists that common man might not immediately understand. To begin with, it is a legal concept, but also an abstraction used, at the same time, by official statements in constitutions or statutory laws and by opinions of legal writers. It is both a concept of the law and a concept of the science of law. As used in constitutional and statutory laws, the concept of the law is not defined and its various configurations seem to be resistant to any unified definition as a concept of the science of law. One needs to evaluate this situation from an historical point of view, then on the basis of constitutional and statutory texts, and finally as a result of an absence of a theory of personal laws. I will then explain my scope and method deployed in this paper.

Jean-Louis Halpérin

jean-louis.halperin@ens.fr

1 Ecole Normale Supérieure, 48, Boulevard Jourdan, 75014 Paris, France 


\section{The Historical Origins of the Wording "personal laws"}

Historically the concept of the science of law predated the concept of law. If the Institutes of Justinian (I. 2. 6) used the wording "personal" ("personales") for some laws of the emperor ("constitutiones"), the qualifying adjective concerned the rulings that were fitted for a unique person (as a reward or a punishment) and were not general norms. This old meaning of the term "personal law" ("leges personales"), as a synonym of privilege, was known only by some specialists of Roman Law during the 19th century.

During the Middle Ages, the glossators used the general text of the first statute of the Justinian's Code (the edict of Thessalonica issued by Theodosius in 380 to make the Nicene Christianity the official religion of the Empire), that alluded to an application to all peoples of the empire ("cunctos populos"), in order to ask the question of the law applicable to a foreigner in an Italian city (the gloss "si Bononiensis" about a trial made to a citizen of Bologna in the city of Modena). It was the origin of the so-called "theory of statutes": the Italian jurists discussed, since the 13th century, if a statutory law concerned persons or things in order to determine if its effects were territorial or extra-territorial. ${ }^{1}$

The term "personal statute" (statute being at this time synonym of law) was not used before a 1584 gloss of a French commentator of the custom of Brittany, Bernard d'Argentré, ${ }^{2}$ who opposed the real statutes (that were the common rule in territorial customs) and the personal statutes. ${ }^{3}$ The Dutch writers, like Rodenburgh in 1653, and the French lawyers of the 18th century, like Boullenois in 1766, ${ }^{4}$ used the synonymous expressions of "personal statutes" or "personal laws" as a fundamental concept of the conflicts of laws doctrine. At the same time, it is noteworthy that the French writers, when studying the ancient Germanic laws of the "leges Barbarorum", spoke of "personals laws" and constructed a theory of the "personality of laws" to explain that every person was submitted to the law of one's "nation" in Western Europe between the 5th and the 9th century. ${ }^{5}$

The 1748 Spirit of Laws from Montesquieu played a crucial role to give a historical pedigree to this idea of ancient laws that were not territorial but linked with the origins of the persons. ${ }^{6}$ This common language about personal laws in France explained that the drafters and the commentators of the 1804 Napoleonic Code considered that article 3 of this Code $^{7}$ was based on the idea of extra-territoriality of "personal laws". This term continued to be a motto for the doctrine of conflict of laws or private international law. It is notable that Dicey's book on The Law of Domicil as a Branch of the Law of England (1879) was translated in French with the title

\footnotetext{
${ }^{1}$ Meijers (1934).

${ }^{2}$ De statutis personalibus et realibus.

${ }^{3}$ Lainé (1888, p. 313).

${ }^{4}$ Traité de la personnalité ou de la réalité des lois.

${ }^{5}$ Guterman (1990, pp. 28 and 273).

${ }^{6}$ Markovits (2008, p. 90).

${ }^{7}$ Saying that "law concerning the status and the capacity of persons govern French persons, even those residing in foreign countries".
} 
Le statut personnel anglais. ${ }^{8}$ At this time, the term "personal status" (and not "statute" as in the older literature) was used as synonymous of personal law system and I will use it to qualify the legal regime organized by personal laws. Some statutory laws continue today to refer to "personal law" in order to resolve conflicts about the law applicable to a marriage between persons of different nationalities. It is the case, for example, of the article 202-1 of the French civil code in the 2014 adapting to the recognition of same-sex marriages.

\section{The Use of the Term "personal laws" in Constitutional and Statutory Texts}

Let us leave legal history for now to instead see some constitutional texts that are in force today, notably in Asia. In the 1926 Constitution of Lebanon, we read that the State "shall also guarantee that the personal status and religious interests of the population, to whatever religious sect they belong, shall be respected". In the 1957 Constitution of Malaysia, article 12 about equality of persons before the law contains a clause (5) providing that "this article does not invalidate or prohibit any provision regulating personal law".

The same sentence can be found in clause (3) of the article 12 of the 1965 Constitution of Singapore. Article 227 of the 1973 Constitution of Pakistan speaks about the "personal law of any Muslim sect" as well as the "personal laws of nonMuslim citizens" (clause 3). In Africa, the 1966 Constitution of Botswana was the first to introduce, in its article 15, the banning of all discriminatory provision in law by virtue of an exception ( 4 c) for the laws "with respect to adoption, marriage, divorce, burial, devolution of property on death or other matters of personal law". This clause was reproduced as a standard in the subsequent constitutions of Zambia (1991), Sierra Leone (1991), Lesotho (1993), Gambia (1997) and Zimbabwe (2005 amendment).

The term "personal law" is also used in many statutes of Muslim countries that provided the rules of family law, for example, the 1951 Law of personal status in Jordan, the 1953 Syrian law with the same title, the 1959 Iraqi Law or the 1984 Code of personal status in Kuwait. Whereas the Indian constitution does not use the term "personal law" it is part of the title of the 1937 Muslim Personal Law (Shariat) Application Act and it is usual to speak of a "personal laws system" to characterize the diversity of family laws that are applied to Hindus, Muslims, Sikhs, Christians, Parsis and Jews. ${ }^{9}$ In India, the Hindu Marriage Act, 1955, is also applicable to Sikh, Jain and Buddhist population. Individual conversion is likely to change the personal law of the concerned person. ${ }^{10}$ However, collective conversions to Islam did not prevent some communities, as the Cutchi Memons, to retain a part of Hindu personal law. In Estate v. Abdul Sattar Sait, the Indian Supreme Court ruled that the inheritance of certain Indian Muslim community was ruled (before the application of the

\footnotetext{
${ }^{8}$ (1889, The English personal status).

9 Ahmed (2016).

${ }^{10}$ Desai (2008), p. 185. Conversion does not dissolve a marriage concluded under the past personal law, but it provides a ground for divorce.
} 
Cutchi Memons Act of 1938) by Hindu Law and not by the Shariat. ${ }^{11}$ Besides India, the plurality of the personal laws is considered a specific feature of at least sixteen States in Asia. ${ }^{12}$

\section{The Absence of a Theory of Personal Laws}

Despite its presence in many constitutional and statutory texts, the concept of personal law is absent from the literature about jurisprudence or legal theory. It can be explained by the fact that the mainstream literature, from Kelsen to the different forms of American and Scandinavian realism, developed without much interest in the Asian or African system. The legal theory thus overlooked the plurality of personal statutes. This diversity of laws coexisting in the same country is a central point of the "pluralist theories of law". Yet, the advocates of a strong legal pluralism have not theorized the concept of personal law, even when they consider the plurality of personal laws as based in an "equitable harmonisation". 13 The hesitation between the singular form, that is used in Muslim countries with sole family law, ${ }^{14}$ and the plural form that fits countries with a plurality of state-enforced religious laws ${ }^{15}$ is the proof of a gap in the current conceptualization of this legal term that concerns large populations in the world, notably in Asia.

If some legal texts contain an enumeration of matters concerned by personal laws (for example, in article 2 of the 1937 Muslim Personal Law in India), ${ }^{16}$ there is no definition of this expression either in constitutional or statutory statements or in doctrinal opinions. If we look at the quoted articles of the Lebanon and Malaysia/Singapore constitutions, many questions arise. For the former, what is the "personal status" of the "population": does it mean a personal law for the whole population or a plurality of laws for different "people" according to their belonging to a "religious sect"? Almost every word of this clause is ambiguous, so is the notion of guaranteeing the respect of this law that could appear as the promise of an eternal clause maintaining status quo. In the text of the Malaysian and Singaporean Constitution all the provisions "regulating personal law" are derived from the principle of equality: a literal interpretation could lead to neutralize the principle of equality in all laws concerning persons, what could be extended finally to all statutory laws!

\footnotetext{
111972 AIR 2229, 1973 SCR (1) 231.

12 Lebanon, Israel, Indonesia, Malaysia, Singapore, Sri Lanka, Pakistan, Bangladesh, Thailand, Syria, Jordan, Philippines, Iraq, Iran, Bahrain.

13 Menski (2006), p. 274.

14 Nasir (2009).

15 Sezgin (2013).

16 Notwithstanding any custom or usage to the contrary, in all questions (save questions relating to agricultural land) regarding intestate succession, special property of females, including personal property inherited or obtained under contract or gift or any other provision of Personal Law, marriage, dissolution of marriage, including talaq, ila, zihar, lian, khula and mubaraat, maintenance, dower guardianship, gifts, trusts and trust properties, and wakfs (other than charities and charitable institutions and charitable and religious endowments) the rule of decision in cases where the parties are Muslims shall be the Muslim Personal law (Shariat).
} 


\section{Scope and Method}

References to personal law provide one of the best example of "undetermined norms". Following an analytical method based on texts, this paper looks for a clarification of debates about personal laws. First, I would like to show that this high degree of un-determination of the norms is the result of different factors: constitutional and statutory texts are particularly vague about the classification (often on religious basis) of persons concerned by these laws, personal status appears as linked with marriage, but without a defined extension to other matters and with great fuzziness concerning interfaith relationships. For explaining this legal chaos, I would argue that this un-determination has important outcomes and is probably willed by the legislators. The lack of any doctrine about this subject is not a reason, as I would show in second part, to continue to use this term without any definition and to abandon the project of constructing a determined concept of personal law inside the legal science. On the contrary, I will defend the idea that the construction of a defined concept of personal laws is useful for comparing these diverse configurations and for discussing the theories of legal pluralism as well as for launching new empirical studies.

\section{The Un-determination of the Classification of Persons Concerned by Personal Laws}

In countries that know a plurality of family laws among their citizens, the undetermined character of norms relating to personal laws is first linked with the vagueness of provisions that define the belonging of a person to a community as the condition for being submitted to a specific law in family matters. If we take again the constitution of Lebanon, its article 9 is interpreted in the context of the "political confessionalism" that was established in 1943 and planned to be progressively suppressed in 1989-1990.

At the moment of the end of the French mandate and of the independence of Lebanon in 1943, the President of the Republic and the Prime minister made an unwritten gentleman's agreement that organized the repartition of seats in the Parliament and in the Government between the Maronite, the Sunni, the Shia and the Druze communities. ${ }^{17}$ Although the Taif agreement of 1989 (then the amendment of the Constitution, notably of the clause $\mathrm{H}$ ) of its preamble) had fixed the abrogation of this political confessionalism as a "national goal", it has kept the attribution of one half of seats in the Parliament respectively to Muslim and Christian deputies. One of the consequences is also the quasi-constitutional status of the eighteen religious communities that have been recognized until today: ten Christian communities recognized through a 1936 ruling (arrêté no 60 LR, decided on the 13th of March, 1936 under the French mandate and never abrogated), the Protestant and Coptic communities that were recognized later (in 1938 and in 1996), five Muslim communities

${ }^{17}$ Hanna (2017), p. 32. 
(the Sunni, the Shia and the Druze ones that are alluded to in the 1943 Pact, the Alawi community recognized by a 1995 law, the Ismaili community that is counted among the 18 communities) and one Jewish community. ${ }^{18}$

This interpretation of article 9 of the Lebanese constitution, supposing that there are as many personal laws as "religious sects", stands on egg-shells. First, the Ismaili community is not officially recognized and one can doubt that this community has its specific personal law. Second, the Jewish community is today reduced to a few hundreds of persons and its personal law is no more applied by a rabbinical court. For each of the sixteen other communities, there is without doubt a personal law that is applied by communal judges (who are state judges for the Muslim communities and religious judges for the Christian communities according to a statutory law of the 2nd of April, 1951). But there is no statutory law to determine clearly how the membership to a religious community has to be proved: during the period of the French mandate, the question of the status of children born in interfaith marriage was very controversial. ${ }^{19}$ Furthermore, the French regulations of 1936 and 1938 have spoken about persons not belonging to a religious (or "historic") community who could be submitted to common civil law.

However, the situation could seem relatively clear for a long time in Lebanon, because the common practice has led to writing down membership to a religious community in the population registries at the moment of the birth, or in the electoral registries to facilitate the political confessionalism, the silence of the law of the 7th December, 1951 about the civil registries notwithstanding. But later, in 1969, the Beirut Court of Appeal has decided to suppress this mention of religious affiliation on identity cards and passports, whereas the Civil War has led more and more Lebanese people to be discrete about their religious belonging. Neither the political confessionalism, nor the "confessional citizenship" has disappeared. Lebanese who want not to be legally linked with a religious community have to ask for deleting the mention in the civil registry or for adding a conversion. ${ }^{20}$ It is a necessary step for couples that have attempted since 2013 to contract a civil marriage in Lebanon.

It appears that this religious enrolment in population registries is an unusual institution in countries with a plurality of personal statuses. It was also the case in Israel according to the 1965 Population Registry Act that has foreseen the mention of nationality/ethnicity for Jews and 135 other national groups, ${ }^{21}$ but this mention was expunged from identity cards in 2002 and some demands of cancellation have been admitted since 2010 .

In Indonesia, the 2013 Civil Administration has ordered the mandatory mention of one of the six religions (Muslim, Protestant, Catholic, Buddhist, Hindu, Confucian) in the population registry, but that rule has been overturned in November 2017 by the Constitutional Court. This ruling concerns native-faith followers in Indonesia,

\footnotetext{
18 White (2011), p. 174.

19 White (2011), p. 187.

${ }^{20}$ Hanna (2017), p. 98-99.

21 Dinstein (1989), 327 about the 1970 Amendment imposing the definition of a "Jew" in Israel.
} 
and it is not likely to suppress any mention of the religion in population registries. ${ }^{22}$ However such rulings show the discrimination problems created by the statutory norms that, in a small minority of states, have tried to define the persons subjected to personal statuses on the basis of population registries.

For the great majority of countries with a plurality of personal laws, one has to rely on more vague definitions of the sphere of application of some family laws and on the declarations of the claimants. Let us take the example of India. Nowhere in the Indian constitution exists a list of personal laws or a method to identify the belonging of any citizen to a religious community. The basic rule has to be found in section 2 of the 1955 Hindu Marriage Act. According to this section 2,

[T[he Act applies (a) to any person who is Hindu by religion in any of its forms or developments, including a Virashaiva, a Lingayat or a follower of the Brahmo, Prarthana or Arya Samaj; (b) to any person who is a Buddhist, Jaina or Sikh by religion and; (c) to any other person domiciled in the territories to which this Act extends who is not a Muslim, Christian, Parsi or Jew by religion, unless it is proved that any such person would not have been governed by the Hindu law or by any custom or usage as part of that law in respect of any of the matters dealt with herein if this Act had not been passed.

In this section, there is the combination of an inclusive approach of persons considered as Hindus (with the submission to the same Hindu law of the believers of the different forms of Hinduism and of the Buddhist, Jain and Sikh peoples) and of a negative definition: it is supposed that other persons submitted to different personal statuses are necessarily Muslims, Christians, Parsis or Jews and that there is no alternative solution for an Indian citizen.

But there is also a room for persons who are neither Hindu, nor Muslim, Christian, Parsi and Jew and a special clause (2) for the members of scheduled tribes. In the same section 2, the "explanation" defines Hindu persons as children of both Hindu parents or persons of one Hindu parent that are brought up as member of an "Hindu" group or persons converted to Hinduism.

Such legal definitions cannot resolve all the questions. As any reference to the religion or ethnicity of the parents, the section leads to a probatio diabolica or to draw an inference in the infinity: how to prove that the parents are Hindus, without proving that the grand-parents were Hindus and so forth? Furthermore, it is known that Hinduism is linked with birth and that even the principle of conversion is religiously controversial.

In the famous case of the succession of Sanjay Gandhi, the Delhi High Court decided that a child born from a Parsi father and a Hindu mother was submitted to Hindu personal law, because he was brought up in Hinduism after the marriage of his parents according to Vedic rites. ${ }^{23}$ It is well known that the issue of conversion can lead to difficult conflicts before the courts about the validity of an "Hindu" marriage, in the cases in which the Hindu character of one spouse is contested.

22 The Jakarta Post, November, 7, 2017.

23 Desai (2008), p. 102; Maneka Gandhi v. Indira Gandhi, AIR 284 Del 428. 
Generally speaking, different personal laws are said to be applied to "Muslim", "Christian", "Jews" persons. Some of them exclude Muslim persons and organize a personal status for non-Muslim persons through a negative definition (for example in the section 3.3 of the Malaysian 1976 Marriage and Divorce Act that does not apply to Muslim persons or in the 1962 Women Charter in Singapore, art. 3 (4)). In case of conflict and in the absence of an official affiliation, judges take account of the religious attitude of the person or of her/his declaration.

In Senegal, succession rights are determined according to the general inheritance law (art. 396-515) or Islamic inheritance law (art. 571) for persons expressing an "uncontested will" to be submitted to this law. It is a very original situation that gives apparently great freedom for the Muslim majority of the population as well as for non-Muslims. The explicit reference to "Muslim law" in the Code and the means used to prove the intent to be submitted to a Muslim succession show that the belonging to a religious community is present to determine the application of a personal status. But, at the same time, there is a great uncertainty about the persons that are submitted (according to their choice) to the Muslim status.

The law of Senegal is an exception because there is much risk of legal insecurity if one lets persons choose their personal status by a simple declaration, as it was the case with the so-called professio legis in the Early Medieval Period in Europe. ${ }^{24}$ This is not the probable goal of the constitutions and statutory laws that refer today to "personal laws".

Personal law must be understood as the law of one's religious community. As the concept of "religion" is very difficult to define in law (and remains not defined in domestic and international law), ${ }^{25}$ the common interpretation looks at the religion of the parents, that is proven prima facie by the religious character of their marriage. As I have said, this presumption is used to avoid the proof in infinitum of the ancestors' religion and it is based on the frequency of endogamous marriage in Asian and African societies that know a plurality of personal statuses.

\section{A Status Based on Marriage?}

For this reason, all the systems of personal laws are based on marriage and on the predominance of affiliation through marriage, that remains a common feature of African and Asian societies, contrary to the European ones. If some countries (like India or Indonesia with a 1974 unique law of marriage subjecting the spouses "to the law of religion and beliefs of both sides") make a clear link between the different kinds of marriage and the diverse personal laws, other countries make only a distinction between "monogamous" and "polygamous" marriages.

It is the case, for example, in the 1971 Tanzania Marriage Ordinance, whose art. 10 says that the marriage contracted "in Islamic form" is "presumed, unless the contrary is proved, to be polygamous or potentially polygamous" and that, "in any

${ }^{24}$ Depreux (2001, pp. 57-58).

25 Gunn (2003). 
other case", it is presumed to be monogamous. Not only this statutory law considers that a Muslim husband can contract a marriage in civil or Islamic form (art. 25), but it does not say clearly how many forms of religious marriages are admitted in Tanzania.

The marriage law of Cameroon (1981 ordinance modified in 2011) is even vaguer, when it refers to the choice of the spouses for a monogamous or polygamous marriage (art. 49). In Cameroon, like in Ghana, polygamous marriages can be customary and non-Islamic marriages. In Cameroon, a 1985 ruling of the Supreme Court stated that "Muslim law is not a Cameroonian institution or a custom", introducing more uncertainty about the distinction between Islamic and customary marriages. ${ }^{26}$

If one admits that personal laws are determined through marriage (for the spouses and for their children), one has to resolve another question about the extension of the legal field linked with the law of marriage. It seems logical to insert the rules of divorce into the law of marriage and to consider that personal statuses determine different laws of divorce (from the Islamic repudiation or talaq, to the more restrictive conception of separation in Christian marriages). The question is less easy for maintenance and children custody, even if the link with the law of marriage remains strong on the basis of the frequency of marriages and of the scarcity of children borne from an unmarried woman. Here again, the system presumes that children can be affiliated by birth to the community of their parents or, in the absence of marriage, of their mother.

The issue is far more complicated about inheritance law and succession rights. It is not necessary that a deceased person, who is considered individually, has kept the personals status of her/his birth or of her/his marriage and that all her/his relatives (possibly endowed with succession rights) have the same personal status. Not only, one has to take account of conversions of status (generally speaking, religious conversions that can happen just before the death), but many countries seem to dissociate the personal laws of marriage and of inheritance. Egypt has, since 1943, a unique law of succession that is based on Islamic-inspired rules and that prohibits the succession between Muslims and non-Muslims. ${ }^{27}$ The Israeli law of inheritance is also unified by a 1965 Succession Law. Indonesia knows five kinds of religious marriages, but three sets of rules for inheritance: the civil one ruled by the Dutch Code, the Muslim one and the adat one, what means that the succession of a Muslim deceased can be ruled either by Islamic law or by adat law.

In Tanzania, there are four systems of inheritance: the common law inherited from the British (that is ruled by the 1865 Indian Succession Act), the Islamic law, the customary law and the Hindu law. Even if the last one seems theoretical, there is no correspondence with the two different forms of marriage. Whereas in India each of the five religious communities has its rules of inheritance, in Malaysia there is on the one hand sharia rules of inheritance for Muslims and statutory rules of inheritance for non-Muslims. There is a comparable situation in Lebanon with a statutory law of inheritance for all non-Muslim citizens. The rules about adoption are

\footnotetext{
${ }^{26}$ Ebi (2012).

27 Bernard-Maugiron (2010).
} 
sometimes common to all the citizens, notwithstanding the fact that adoption is not allowed in the Muslim tradition and that judges have to use, as in Indonesia, the possibility of bequests for allowing a Muslim person to give one part of the succession to an "adopted" child.

As a result of this diversity of situation, personal status appears as a heterogeneous set of rules that has not always the same extension, whereas it is not defined by the constitution or by a single act. Paradoxically, the matters submitted to personal status are only defined in the African constitutions following the Botswana model, the first constitution to except from the prohibition of discrimination the rules concerning "adoption, marriage, divorce, burial, devolution of property, and other matters of personal status".

If, in these countries, there are different forms of marriage because of the admission of customary marriages besides civil marriages, inheritance law can be unified or determined by the territorial belonging to a tribe, which makes difficult (if not impossible) the comparison with Asian countries recognizing different statuses according to the qualities of the persons. Malaysia is an exception case with a constitutional provision speaking of "Islamic law and personal and family law of persons professing the religion of Islam, including the Islamic law relating to succession, testate and intestate, betrothal, marriage, divorce, dower, maintenance, adoption, legitimacy, guardianship, gifts, partitions and non-charitable trusts" (Ninth Schedule, Federal List, art. 4e).

For these reasons, it is not so easy in some cases to determine surely the number of personal statuses. Five personal statuses are clearly recognized in India. We know that there are fourteen religious communities in Israel who are supposed to have a personal law and specific courts. However, there is some doubt about the existence of Baha'i or episcopal courts with their personal laws of marriage and divorce. Furthermore, the Greek Catholics, the Armenian Catholics and the Syrian Catholics have transmitted their rights to Catholic ecclesiastic courts. ${ }^{28}$ In Lebanon, doubts may be raised about the hypothetic Jewish status today, while the Ismaili community is not legally "organized".

In Egypt, fourteen non-Muslim religious communities have been recognized (four Orthodox, seven Catholic, one Protestant and two Jewish, the last ones being a dead letter today), whereas one speaks only of the Muslim or of the Coptic statuses and despite the existence of unified inheritance law.

In Cameroon, there are apparently three statuses, the civil one with the application of the French model of the Civil Code, the Muslim one and the customary one, knowing that there are a great number of customs with different inheritance rules. In all these countries, it is difficult to agree about the number of personal statuses, especially as some of these statuses are expressed in non-codified rules, the one of the sharia that can be different between the diverse Muslim communities or the one of the customs that are not written down.

${ }^{28}$ Sezgin (2003, p. 90). 


\section{The Uncertain Issue of Interfaith Marriages and Inheritances}

Finally, the last uncertainty concerns interfaith marriages and interfaith inheritances. In some countries like Israel and Lebanon (with some nuance since the apparition of some civil marriages according to the "French" civil law that is kept in force through the 1936 decree) ${ }^{29}$ mixed marriages in a civil form are prohibited in the national territory, but can be contracted abroad and recognized. In other situations, like the one of India, the "special marriage" provides a solution for mixed couples with a specific status for marriage and divorce, but the submission to Hindu inheritance law.

Can we say that the Indian couples contracting a special marriage are submitted to a sixth personal law? The answer is dubious. In Indonesia and in Malaysia, the courts had to answer the question of interfaith marriage or inheritance because of the silence of the law. This silence has been interpreted as allowing interfaith marriages and recognizing succession rights to heirs with different religions. It means that the judges have to construct a rule of conflict of personal laws and to develop a legal regime for this kind of situations, despite the absence of statutory provisions.

If other States (like France or United Kingdom without the recognition of different personal statuses among their citizens) know the importance of case law to resolve these issues of private international law, the un-determination of the wording "personal laws" adds an element of complexity in countries with a plurality of personal laws. It can be said that this plurality works well because of the intervention of judges and, in many countries, of the rarity of interfaith marriage or inheritance. However, from the point of view of observers or of legal science, it is not meaningless to look at the reasons for such an undetermined notion and at the possibilities to construct a determined concept.

\section{Overcoming the absence of statutory definition of personal laws}

In order to overcome this absence of statutory definition of personal laws, it is useful first to explain its historical origins and its political justification. Then I will discuss the theories of legal pluralism concerning this subject and I will propose a definition that is likely to launch new empirical studies in comparative law.

\section{Taking Account of the History of the Wording}

How can we explain that a group of more than two dozen of countries in Asia and Africa use this wording "personal laws" without defining it? If personal laws correspond often to religious and traditional rules, supposed to reflect the habits of indigenous peoples, the wording is from the Western origin as I have explained in the introduction. Whereas the European colonizers in America have massively transplanted their legal rules (largely based on Roman law at the beginning of the

${ }^{29}$ Hanna (2017). 
colonization by Spanish and Portuguese rulers), refusing to recognize the existence of any indigenous law for the Amerindians, colonialism took other ways in Asia and Africa. Portuguese colonizers were the first to consider that in their factories in India, Ceylon or China (Macao) they could not evangelize all the population and that it was more efficient to keep the religious or customary rules of indigenous peoples.

They wrote down the first books of customary laws for judges (foral or 1597 convention of Malwana in Ceylon). Then, the Dutch and the British, in Ceylon, ${ }^{30}$ in Bengal and in the rest of British Indies (1772 Regulations of Warren Hastings about inheritance, marriage, caste and religious cases judged according to the Quran or to the Sastras with respect to Mohammedans and Gentoos), ${ }^{31}$ or the French in their comptoirs de l'Inde (1769 ruling confirmed in 1819, Gentoos and Muslims judged according to their morals and customs, with a special court called Tribunal de la chaudrie $)^{32}$ followed the same policy. It was used later in Africa, for example with the 1830 conquest of Alger by the French promising to respect religion, properties and wives of the inhabitants.

Probably Christian colonizers took inspiration from the treatment of dhimmi (People of the Book, Jewish and Christian communities) by Muslim rulers, especially inside the Ottoman Empire (with the millet system granting to these communities their religious courts). There were also points of contact with the privileges of extraterritoriality conceded by the Ottomans to European merchants through the "capitulations", because civil cases as well as criminal ones between Christian traders were settled by their consuls. ${ }^{33}$ However, none of these legal statements use the wording "personal laws".

One has to wait till the end of the nineteenth century to find the linguistic transplantation of the Roman expression in Arabic. When the Egyptian minister Qadri Pasha made a draft of Family Law (that was never adopted) in 1875, he called it Personal Status Code and he created the Arabic wording "al-ahwal al-shakhsiyya" as opposed to "real status" or civil rules. At this time, the model of the Napoleonic Code was very influent in Egypt.

Article 3 of the Napoleonic Code said that the "laws concerning the status and capacity of persons" govern French people, even if they were abroad. Using the old "theory of statutes", the commentators of the Napoleonic Code have spoken about the "personal law" following French people in their circulation outside the French borders. As it was necessary to settle conflicts of laws in Egypt and that mixed courts were created to judge cases between Christian traders and indigenous people, Qadri Pasha thought efficient to apply this rule of the extraterritoriality of personal law to all litigants in family cases. It was something audacious and troublesome because there was no category in the sharia corresponding to personal law. Qadri Pasha cut off one part of the Koranic and Sunna rules to constitute his Code of Personal Status.

\footnotetext{
${ }^{30}$ Cooray (2003, pp. 4-5).

31 Mallampalli (2010) shows how the proof of one's customs could be used in order to escape to personal law in the first decades of colonization, before being abandoned for more rigid rules after 1860 .

32 Bonnan (1999).

33 van den Boogert (2005), Tait-Slys (2014).
} 
Later, European colonizers use this wording for different indigenous people and the Ottoman rulers, after codifying the civil law of property and obligations in the 1876 Mecelle, codified separately the Muslim personal status in a 1917 Family Law.

\section{Explaining the Status Quo}

As it was directly linked with colonialism (or quasi-colonialism like in Egypt), this wording of "personal laws" could have been abandoned after decolonization, especially in countries that kept only one personal law (the one of the indigenous people, inspired in many countries by the Islamic law) and did not recognize specific rights to religious minorities after the emigration of the great majority of European settlers (like in Algeria, with the application of the same personal law to all citizens, including those converted to Christianity). It is the historical reason why some Muslim countries continue to qualify their family law as a "code of personal status", whereas it is the unique and common law and that there is no difference between personal and real law, except for the application of the rule of conflict in international private law (exactly as in countries with a long tradition of unified legislation).

In Asian and African countries with a plurality of religions and of personal laws, the general trend was to keep an equilibrium between the different communities. It was the reason until today of the provision of the 1926 Lebanese constitution (continuing the quasi-colonial rule of the French mandate) or of the policy followed by the State of Israel (as a compromise after seeing the absence of a consensus about the secular or religious nature of the State), which have maintained the millet system (recognizing communities with their religious courts and laws) inherited, like in Lebanon, from the Ottoman period, then from the British mandate.

One knows that in India the promise of a uniform civil code did not prevent legislators to codify separately Hindu family law and to keep the five personal laws recognized by British colonizers (including the Jewish status that concerns a tiny population). In Pakistan, then in Bangladesh, the Hindu and the Christian status continued to be ruled by specific rules (many of them maintaining the British statutes), whereas the Hindu and the Christian communities are very small and not likely to provide new case law through courts. Indonesia has adopted in 1974 a unified law of marriage, but this law refers to the law of religion and beliefs of both sides. Since the 1970s, Soeharto's government, then the elected governments after 1998 have reinforced the competences of Islamic courts applying the Islamic personal status to the great majority of the population, but letting the religious minorities submitted to civil (that means to the Dutch Civil Code) or adat law. In all these countries, the diversity of personal statuses based on religious affiliation was not abandoned. Only some African countries chose to replace the diversity of customary laws by a unique Civil Code (that can be inspired partly by the Islamic normativity like in Mali). There is a great probability that the absence of definition of personal laws has its origin in these cautious policies maintaining the status quo.

Governments do not want to transform inherited situations with the risk of one part of the population dissenting. The fears of Muslim Indians to be submitted to a unified code from Hindu inspiration or the current debates in Indonesia about the 
idea of abandoning the Dutch criminal and civil codes show that it is very difficult to reform personal laws. The vagueness of constitutional or statutory provisions, even to determine the number of different statuses, has been considered in all concerned countries as the best way to maintain a "peaceful" respect of the diverse communities. It does not mean that the post-colonial States are weak and that the personal statuses are eternally frozen, ${ }^{34}$ but that it is rather costly to abandon these family laws based on the plurality of personal statuses.

\section{A Proof for a Strong Pluralism or an Argument for Weak Pluralism?}

The keeping of a plurality of personal laws could be interpreted as a proof of the strength of legal pluralism in many Asian and African countries, as opposed to the Western legal centralism. If we use Griffiths' definition of "strong pluralism", is it not possible to say that the plurality of personal laws corresponds to the presence on the same territory of different "legal orders", some of them being composed by "non-state" laws? ${ }^{35}$

In these non-state laws, one could classify the religious norms, as based on Scriptures and on traditional doctrines (for example, those of fiqh for Islamic law), as well as the customary rules, as supposed to form a spontaneous law emerging from the peoples' practices. I do not think that such an analysis can explain the current situation of the plurality of personal laws. These laws are not defined in an autonomous way by religious authorities that could act independently from the State.

On the contrary, the plurality of personal laws is organized by the State: in some cases, the State enacts its own laws to regulate the status (as in Muslim countries codifying their Islamic law or in India for the Hindu Code), in other cases the State recognizes religious laws as binding norms for the courts (for example in Israel or in Lebanon, in the last case with a procedure organized by the 1936 decree for "presenting" the religious statuses to the State). ${ }^{36}$ When we speak of "religious laws", it is the matter of rules from religious origin that are "stripped of their divine authority" and transformed in "ordinary laws of the state". ${ }^{37}$ With such a situation blurring the frontier between religious and secular laws, there is a margin of appreciation for the State authorities (the legislator and the courts) for maintaining the traditional statements and interpretations of personal statuses from religious origin, or on the contrary to reform (for example, about polygamy and divorce) some aspects of the rules inherited from the religious normativity.

The fact that some countries have maintained (like in Lebanon and Israel) or reestablished (as in Indonesia) religious courts, whereas other countries know only secular courts (like in India or Egypt) is not relevant to change this perspective of "weak pluralism". When religious courts exist, they are also "recognized" by the

\footnotetext{
34 Sezgin (2013, p. 25) arguing against this "self-reinforcing path".

35 Griffiths (1986, p. 5), Menski (2006, p. 115).

36 Hanna (2017, p. 57): one has to add that the Lebanese State has never officially recognized the statuses that were presented before the state authorities.

37 Sezgin (2013, pp. 44-46).
} 
state, either by a complete integration in the state apparatus (as in Lebanon for the Muslim courts), or by a procedure of control through a Supreme Court. Again, there are clear differences between the policies of self-restraint of some Supreme Courts towards personal laws (as in Israel) and those that are more interventionist in this field (as in Egypt), but there is no reason to separate plurality of personal laws and "weak pluralism". Today there is no system of plurality of personal laws outside the recognition and the organisation of such laws by the State.

If one is looking for common features in all legal systems with a plurality of personal laws (that is a requisite for determining a doctrinal concept of "personal laws"), it seems to me necessary to make a demarcation between these systems and the question of the use of "customary laws".

Of course, personal laws and customary laws can overlap: some personal laws refer to customary rules (for example, about the formation of marriage in the Hindu Marriage Law in India), and customary rules can be applied to "personal matters", like marriage, divorce, guardianship and inheritance. However, customary rules also concern land law or commercial law that are outside the sphere of family law, which is the core of personal statuses. In many African countries, including those referring to matters of personal status in their constitution (like Botswana, Zambia, Lesotho, Zimbabwe), there is a recognition of customary marriages and the possibility of combining a general set of common rules of inheritance (like in Zambia) with the use of derogatory customary rules. In these cases, it is not the matter of a personal status regulating all the family life of a person from her/his birth to her/his death. In these countries, judges do not have to determine if a person is ruled by a personal status, but if a case (one of marriage, of divorce, of guardianship or of inheritance) is ruled by customary law. Generally speaking customary law is territorial: traditionally, it is determined by the residence of the concerned persons in the territory of a tribe or inside an ethnicity.

For a long time, these persons spend all their life in the customary territory in which they were borne. Today, there are more and more moves of populations toward the cities and the constitution of "urban" or "peri-urban" customs that concern mainly land law, but are likely to interfere with the application (or non-application) of customary rules to family matters. ${ }^{38}$

Because customary rules are more territorial than personal, more derogatory than general and more dependent from the judges' arbitrary, they are not identical with personal laws. If one is looking for a defining a doctrinal concept of personal laws, in order to compare the diverse manifestations of a same concept in different countries, it appears that the dichotomy between legislated and customary rules is not the same that the one between unified or plural personal status. Returning to the historical use of this wording in Asia and Africa, one cannot under-evaluate the importance of the religious factor. In the colonial period, personal laws were organized by Christian colonizers who considered that it was impossible to evangelize the indigenous peoples and that it was more expedient to dominate these peoples, while maintaining (and controlling) their religious laws.

38 Woodman et al. (2004, p. 222 about Tanzania). 
As we have seen, post-colonial States have maintained the wording "personal law (or personal status)", let it be for situations of a unique personal status (in those situations the wording has lost any meaningful impact) or for those situations of plurality of laws we are interested in. In many cases of plurality of personal laws, the application of a personal status is determined by the belonging (generally by birth, in some cases through conversion) to a religious community recognized by the State (for example, in India, Pakistan, Bangladesh, Sri Lanka, Lebanon, Israel, Cameroon). In other countries, there is a distinction (especially for inheritance law) between Muslim and non-Muslim citizens, as in Malaysia or in Indonesia (with the complication resulting of the possibility for a Muslim or a non-Muslim citizen to be ruled by adat law for inheritance). Senegal seems to be a special case, without a direct link with religion. According to the 1972 Family Code, spouses can choose the civil registered marriage (art. 116 of the Family Code, with the option for monogamy, or limited polygamy, whereas in the silence of the parties, polygamy is authorized until four marriages) or the customary marriage (art. 114). The form of marriage is not completely determined by religion. Succession rights are determined according to the general inheritance law (art. 396-515) or Islamic inheritance law (art. 571) for persons expressing an uncontested will to be submitted to this law. It is a very original situation that gives apparently great freedom for the Muslim majority of the population as well as for non-Muslims.

However, the explicit reference to "Islamic law" in the Family Code of Senegal and the means used to prove the intent to be submitted to a Muslim succession show that the belonging to a religious community is still a decisive factor: it would be difficult to apply the Islamic inheritance law to a non-Muslim, whose choice of law could appear to be arbitrary and not "uncontested" as says the Code. The Senegalese system is less rigid than in other countries with personal statuses (it lets a margin of choice for the concerned persons, as in India with the special marriage), but it is based on the distinction between a Muslim status and one (or two, according to the possibility of customary marriage) non-Muslim status.

We do not know countries with a plurality of personal statuses that do not recognized a special status for Muslim citizens, either they are majority (in Pakistan, in Bangladesh, in Indonesia, in Malaysia, in Lebanon, in Morocco, in Senegal, in Tanzania, in Sierra Leone or in Gambia) or minority (in Israel, in India, in Sri Lanka, in Philippines, in Thailand, in Cameroon, in Ethiopia, the determination of the majority being uncertain in Nigeria). It does not mean that Islamic law is the "problem" of the plurality of personal laws, but that historically the strength of the Islamic normativity has led to situations of a plurality of personal laws in States with a multiconfessional population that have decided to maintain this plurality.

\section{Conclusion: A Stipulative Definition as a Tool for Empirical Studies}

For these reasons, I propose the following (and stipulative) definition for identifying the countries with a plurality of personal laws: a legal order with a plurality of personal laws contains a set of differentiated rules (that is, different from the rules applied to other nationals) determining a family legal status, based on the belonging 
(or non-belonging) to a religion-based community, acquired by birth or marriage, with or without the possibility of choice. By "family legal status", we mean a corpus of legal rules concerning the family: not only different forms of marriages that can exist in countries without a system of personal laws, but different rules concerning divorce, rights of spouses, filiation, adoption, possibly inheritance (in a minimal way for the quality of heir and the prohibition of interfaith inheritance as in Egyptian law). ${ }^{39}$ The "belonging to a religious-based community" excludes African legal systems based on the distinction between customary communities (rather based on territorial rather than personal rules) and "general law" (linked with civil or religious marriages inherited from the colonial period).

I admit that the linkage with the personal law system is not exclusively based on religious affiliation, in particular when citizens can choose between different personal status options (ex. Senegal, Cameroon) but I consider that this religious component is present in all countries with a plurality of personal laws. With such an analytical concept, twenty-nine countries (Lebanon, Israel, India, Indonesia, Malaysia, Singapore, Sri Lanka, Pakistan, Bangladesh, Thailand, Syria, Jordan, Philippines, Iraq, Iran, Bahrain, Egypt, Morocco, Senegal, Nigeria, Cameroon, Kenya, Tanzania, Ghana, Sierra Leone, Gambia, Ethiopia, Sudan and South Sudan) can been identified prima facie as subjected to this stipulative definition.

The scientific goal of this definition is to base the comparison between these countries on a clear concept: if we know that these legal systems have common features, we can study how they rule common problems (as interfaith marriage or inheritance) and how they deal with the tension between this plurality of personal laws and the principle of equality. The determination of a legal concept does not disregard the empirical complexity of the situations. It makes these different situations likely to be compared on the basis of a minimum of common features. Such a definition is not indifferent to the wording "personal law", but it underlines the vagueness of statutory provisions.

Last but not least, I think that such a definition can be the point of departure of new empirical studies about the current application of personal laws ant that it can help to understand the characteristics of an important group of countries, which have kept this historical heritage of a plurality of personal laws.

\section{Compliance with Ethical Standards}

Conflict of interest On behalf of all authors, the corresponding author states that there is no conflict of interest.

\section{References}

Ahmed, F. 2016. Religious Freedom Under Personal Law System. Oxford: Oxford University Press.

39 Bernard-Maugiron (2010, for the case of Egypt). 
Bernard-Maugiron, N. 2010. L'amendement du règlement sur le statut personnel des coptes orthodoxes d'Egypte: à quand une loi unifiée de la famille? Revue internationale de droit comparé, 62/1: 75-103.

Bonnan, J.-Cl. 1999. Jugements du Tribunal de la Chaudrie de Pondichéry 1766-1817. Institut français de Pondichéry.

Cooray, L.J.M. 2003. An Introduction to the Legal System of Sri Lanka. Pannipitiya: Stamford Lake Publication.

Depreux, Ph. 2001. La loi et le droit. La part des échanges culturels dans les références à la norme et les pratiques juridiques dans le Haut Moyen Âge, Actes du Congrès de la Société des historiens médiévistes de l'enseignement supérieur public 32: 41-70.

Desai, K. 2008. Kumud Desai's Indian Law of Marriage and Divorce. Nagpur: Wadhwa and Company.

Ebi, J.N. 2012. The Place of Muslim law in Cameroon's Legal System. Law and Politics in Africa, Asia and Latin America 45/4: 432-449.

Griffiths, J. 1986. What Is Legal Pluralism? Journal of Legal Pluralism 18: 1-55.

Gunn, T.J. 2003. The Complexity of Religion and the Definition of Religion in International Law. Harvard Human Rights Journal 16: 189-215.

Guterman, S.J. 1990. The Principle of the Personality of Law in the Germanic Kingdoms of Western Europe from the Fifth to the Eleventh Century. Bern: Peter Lang.

Hanna, J. 2017. Statut personnel et religieux. Vers un mariage civil au Liban, dissertation University Paris I.

Lainé, A. 1888. Introduction au droit international privé. Paris: Librairie Cotillon.

Mallampalli, C. 2010. Escaping the Grip of Personal Law in Colonial India: Proving Custom. Negotiating Hindu-ness. Law and History Review 28 (4): 1043-1065.

Markovits, F. 2008. Montesquieu, le droit et l'histoire. Vrin.

Meijers, E.M. 1934. La Théorie italienne des statuts. Recueil des cours de l'Académie de droit international de La Haye 49: 592-635.

Menski, W. 2006. Comparative Law in a Global Context. The Legal Systems of Asia and Africa. Cambridge: Cambridge University Press.

Nasir, J.J. 2009. The Islamic Law of Personal Status. Leiden: Brill.

Sezgin, Y. 2013. Human Rights Under State-Enforced Religious Family Laws in Israel, Egypt and India. Cambridge: Cambridge University Press.

Tait-Slys, M. 2014. Exporting Legality. Geneva: Graduate Institute Publications.

van den Boogert, M. 2005. The Capitulations and the Ottoman Legal System. Qadis, Consuls and Beraths in the 18th century. Leiden: Brill.

White, B.T. 2011. Emergence of Minorities in the Middle East: The Politics of Community in French Syria Mandate. Edinburgh: Edinburgh University Press.

Woodman, G.R., Wanitzek, U. Sippel, H. 2004. Local Law and Globalization: A Comparative Study of Peri-Urban Areas in Benin, Ghana and Tanzania. Münster: Lit.

Publisher's Note Springer Nature remains neutral with regard to jurisdictional claims in published maps and institutional affiliations. 